\title{
Straddling Two Worlds: Christian Leaders' Responses to Witchcraft Accusations in DRC
}

\author{
Mwenda Ntarangwi
}

Growing up in rural Meru around Mount Kenya my siblings and I heard many stories told by our parents and grandparents both as tools of entertainment as well as education. Those stories were a combination of what we today refer to as "edutainment". Reading "Christian Pastors and Alleged Child Witches in Kinshasa, DRC" (Priest, Ngolo and Stabell 2020) took me back to those stories. The article reminded me of the complex world that we live in and its multiple realities. That world entails the daily practice of completing chores, interacting with family and friends, going to school, and eating and sleeping, among others. Then there is the world of the living dead inhabited by relatives or ancestors not physically present with us but near enough to watch over and protect us. And there is also the world of evil where bad spirits reside. Those are the spirits responsible for disease, accidents, evil, and anything bad that happens to people and the community. There were also stories and warnings of what to do and not to do including, don't climb a castor tree; when your palm itches you are going to receive money; when you trip on something on the road someone must have mentioned your name; and if you hear an owl hoot someone will die in the village. We took these cultural realities in stride and made them part of our lives. They informed our sensibilities as we engaged fully with life. We also listened to stories about Christ and being Christians because both our parents and grandparents were Christians. We knew that these two sets of stories had something to do with how we lived and interacted with the world around us. We also learned that Christian stories were considered more important. Sometimes both worlds converged in animal stories meant to teach us certain values that were also Christian. One of the stories that I heard and which stuck with me is a story of a hyena that was walking on the road and smelt food from up ahead. The hyena, we were told, kept going towards the aroma until it came to a fork in the road. The hyena agonized over which branch of the road to follow to get to the food because both had the aroma. In the end the hyena could not decide and took both roads, putting two legs on each of the branches of the road, until it split into two and died. The story was meant to warn us against greed and signal the need to make decisions. As a Christian trained in anthropology I now can see that engaging with the two realities of Christianity and local philosophical thought within which I grew up provided an important formation as a member of a community that converted to Christianity. It is a formation that makes me sympathetic to the practices addressed in this study and may explain why I enjoyed the insights the authors provide.

It seems like the pastors in Kinshasa discussed in this study by Robert Priest, Abel Ngolo, and Timothy Stabell have figuratively had moments akin to that of the hyena-straddling two worlds. They straddle the world of the accusers of children as witches and that of offering alternative narratives and belief based on Christianity. Throughout the paper the authors present church leaders as the new mediators of the accusations of witchcraft (as opposed to traditional healers and diviners) because of their central role in mediating between this and the other world of evil. This is not surprising because as shown in another study that Robert Priest was involved in, African pastors are considered the most influential leaders among Christians in Kenya, Central African Republic and Angola.' Kinshasa pastors are clearly helping respond to modern day witchcraft brought by modernity and its

'See "17 Insights into Leadership in Africa," available at www.AfricaLeadershipStudy.org. 
discontents. As the Comaroffs note, this modern day witchcraft is "a mode of producing new forms of consciousness; of expressing discontent with modernity and dealing with its deformities" (1999, 284). Indeed, Priest, Ngolo and Stabell point to the local conditions of material and political insecurities that bring distress to the city population, and in turn lead to people seeking ways of explaining their misery. Because in the context in which Kinshasa inhabitants live they have to find causality and so they turn to "trusted" methods and ideologies which are anchored in witchcraft. But now that the accused are children, the very future of their communities, the pastors have to negotiate these cultural challenges carefully. They ought to understand, as the Comaroffs continue to state, that dealing with modernity calls for an understanding of modern day notions of witches who play a key role in explaining phenomena, "Because witches distill complex material and social processes into comprehensible human motives, then, they tend to figure in narratives that tie translocal processes to local events, that map translocal scenes onto local landscapes, that translate translocal discourses into local vocabularies of cause and effect" (1999, 286). But the kinds of witches being presented in Kinshasa are seen as bringing about suffering and evil to the people.

As a cosmopolitan city, Kinshasa has its share of these mixed images of modernity and poverty where locals are struggling to reconcile the idea of prosperity and the reality of poverty and suffering. It could also be because children are dependent on adults and adults are by social obligation expected to fend for them. Unable do so these adults find ways of blaming the children for their challenges. When increased material and even spiritual insecurities of this modern age loom large as promises of post-independence prosperity are met with poverty and dwindling opportunities for stability in the family and community, then witchcraft accusations abound. Many migrants to cities find it hard to maintain the community practices they had enjoyed in the rural areas and yet often seek to replicate them. There is actually an interesting relationship between the idea of community and material prosperity that falls into the hands of witchcraft accusations. As Freidus shows for rural Malawi, "the idea of community can be interrogated through the idiom of witchcraft, as it is often considered a gauge of social stability or instability at the village level" $(2011,21)$. One cannot help but wonder how these individuals who accuse children of being witches would reconcile the biblical call by Jesus in Mathew 19:14 to "Let the little children come to me, and do not hinder them, for the kingdom of heaven belongs to such as these." Given that many Kinshasa residents confess to a Christian identity they must find ways of skirting around such a clear message.
After reading through the study I realized that many accusers of child witches get away with it. I saw two things happening through the process of accusing children-first, the accused children have maladies that cannot be easily explained and second, they are such a burden to caregivers that the caregivers need a way out. The best trusted way seems to resort to the culture's belief in what causes evil or what is the source of bad things happening to people. As the study shows there are people who are skeptical of the allegations, but because they are powerless they are forced to go through the regimen. It is, however, good to see that some pastors are not convinced about these accusations and often offer alternative narratives. Such alternative narratives help reorient some beliefs and may lead to social change. Chinua Achebe's classic novel Things Fall Apart provides a similar example of how Christians provided an alternative narrative to local explanations of evil that changed their community's social practices. Achebe writes about the evil forest which was considered to be inhabited by evil spirits lurking in the community. When White missionaries came to the community and asked to be given land on which to settle the community members gave them the evil forest with the assumption that the evil spirits would kill the missionaries. The missionaries were not welcome to the community but the village people did not outrightly kick them out. They wanted the spirits of the evil forest to fight and kill them. But after a while of missionaries living in the evil forest, the local people noticed that instead of dying the missionaries were actually thriving. How could that be? Did they have stronger spirits than the local ones? That would be the beginning of doubt towards the efficacy of the evil spirit narratives and the changes that were to later be registered in that community.

In my own community in Meru, Kenya there was a similar scenario. When the first missionaries arrived in Meru they were given space in a place called Kaaga (a place of diviners) where the local people did not want to settle, and therefore a good place to give to uninvited foreigners. When the missionaries started to thrive the local people started seeing them in a different light, often seeing their practices as more powerful than those of the locals. When people who were otherwise ostracized by the locals for whatever maladies went to the missionaries in the place of diviners (Kaaga) they thrived. Slowly the other local people started to question their own beliefs. Today Kaaga is home to some of the most prosperous individuals in the county including some of the best high schools (Kaaga Girls High School and Meru High School). I was born in Kaaga and know about the history of that place and its significance in the community's Christian heritage. It is these kinds of alternative narratives which challenge local beliefs that Kinshasa pastors are providing through 
the EPED project. These pastors are playing a key role in caring for the ostracized children accused of witchcraft but they are also in a very good position to reconstruct belief systems from traditional to modern, as in the case of Sylvain Mbaki who talks about the mom and son not believing what they were being told about evil. If the church would reaffirm their doubts then the church can successfully challenge received wisdom about maladies that would eventually change cultural assumptions and practices. But the pastors have to be willing to give up their own strategies for manipulating desperate parents or accusers. A good example is the case of pastor Jean who clearly knew that he was playing to the fears and beliefs of the parents when he says, "Others I would put through the process of deliverance, and after the third day, I would make them drink vegetable oil. Of course, if you fast and then drink vegetable oil, you will throw up. When they threw up, I would say, 'See, he just threw up what we were looking for”" (11).

These pastors have to be careful, however, not to send the wrong signals to their communities. They have to straddle between affirming the existence of the world of witchcraft while at the same time believing in the power of Christ to provide deliverance from such a world. Further, given that many of the accusations are driven by material conditions-parents inability to provide for the children they take in due to tough economic conditions-there is a tendency for the church to want to provide material resources to the affected families. In the absence of such support flowing what will happen to the children? Do the churches and pastors or even EPED have enough resources to set families up materially so that they are independent and don't find themselves in another situation of material want and revert to reducing the number of dependents through witchcraft accusations?

Given that $63 \%$ of DRC interviewees answered yes to a question on belief in witchcraft how does such affirmation shape people's religious behavior? One of the driving forces behind the growth of the whole deliverance phenomenon in African church communities is tied to the existence of evil in the form that is akin to witchcraft and these churches scratch where it itches. It is what anthropologist Paul Hiebert called the problem of the excluded middle when he carried out studies of Christianity in India. Hiebert asks of Christians who converted to Christianity but never gave up their traditional beliefs,

What happened to villagers who became Christians? Most of them took problems they formerly took to the saints to the Christian minister or missionary. Christ replaced Krishna or Siva as the healer of their spiritual diseases. Many of them in time turned to Western allopathic medicines for many of the illnesses they took to the doctor and quack. But what of the plagues that the magician cured? What about spirit possession, or curses, or witchcraft or black magic? What was the Christian answer to these? $(1982,39)$.

This scenario described by Hiebert can be found in many other contexts especially in communities where Christianity is introduced to a people who have an existing religious tradition. The people use their already existing religious interpretations to understand life through the new religious framework producing what we can call a religious "accent."

Priest, Ngolo and Stabell show that even when communities are faced with social and spiritual complexities that call for traditional explanations including witchcraft, Christian churches and pastors intervene to offer alternative narratives because they are able to straddle the two worlds. But they have to be careful not to give each side equal weight and end up splitting into two like the hyena in the story given above. One can only hope that those who "convert" to a reality that abandons witchcraft do not revert to their traditional beliefs when faced with new socioeconomic and spiritual challenges. Further, these Christians have to guard against another development that Hiebert warns against, to "guard against Christianity itself becoming a new form of magic" (Hiebert 1982, 46). This paper has provided a good platform for scholars to see how society changes and the role that can be played by a few committed Christian leaders. It is also an example of how theological training that pays attention to social contexts and the need for pastors to have a holistic approach to social practices can be useful in times of need such as those presented by cases of witchcraft accusations of children. It is an opportunity for theology to adopt some of the approaches employed by anthropologists to study and understand culture-holistic, contextual, and comparative approaches.

\section{References}

Comaroff, Jean and Comaroff, John. L. 1999. Occult economies and the violence of abstraction: Notes from the South African postcolony. American Ethnologist 26(2): 279-303.

Freidus, Andrea. 2011. Raising Malawi's Children: AIDS Orphans and a Politics of Compassion. PhD dissertation submitted to Department of Anthropology, Michigan State University, East Lansing, MI.

Hiebert, Paul. 1982. The Flaw of the Excluded Middle. Missiology 10(1):35-47. 
Priest, Robert J., Abel Ngolo and Timothy Stabell. 2020. Christian Pastors and Alleged Child Witches in Kinshasa, DRC. On Knowing Humanity Journal 4(1):1-51.

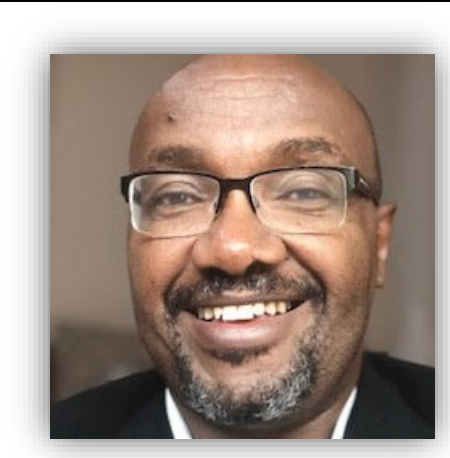

Dr. Mwenda Ntarangwi is the CEO and Commission Secretary for the Commission for University Education (CUE) in Kenya. He holds a B.Ed. (Language Education) and MA (Swahili Cultural Studies) from Kenyatta University and a MA and $\mathrm{PhD}$ (Cultural Anthropology) from the University of Illinois. Dr. Ntarangwi has taught anthropology and other related courses for two decades and carried out administrative work in different capacities including serving as Vice President at Theological Book Network in Grand Rapids, MI; as the Executive Director of IAPCHE and Associate Director of the Office of Off-Campus Programs at Calvin College in Michigan; as the Director of African and African Diaspora Studies (AADS) at Calvin College; and Director and Assistant Professor at St Lawrence UniversityKenya Semester Program. Dr. Ntarangwi, an Associate Professor of Anthropology, is widely published on popular culture, youth, and the practice of anthropology. His publications include The Street is my Pulpit: Hip Hop and Christianity in Kenya, 2016, University of Illinois Press; Reversed Gaze: An African Ethnography of American Anthropology, 2010, University of Illinois Press; Jesus and Ubuntu: Exploring the Social Impact of Christianity in Africa, 2011, Africa World Press; East African Hip Hop: Youth Culture and Globalization, 2009, University of Illinois Press; and, Engaging Children and Youth in Africa: Methodological and Phenomenological Issues, 2015, CODESRIA Books (co-edited with Guy Massart).

Author email: mwendantarangwi@gmail.com 